\title{
Pemilihan Kepala Daerah Secara Langsung di Era Otonomi Luas
}

\author{
Ni'matul Huda
}

The discourse of regional (provincial and residential) leader direct election arises due to the miscellenaeus deviations apparent during the process of regional governors, residents or munipalcities across the country. This deviations may in the form of money politics, required documents falsification, the less capability (under minimum required standard), or because of either from political party or central government intervension, which are mostly are not parallel with the local people aspiration. Therefore, through direct election, local people are able to directly choose the political leader they want.

$\mathrm{H}$ ampir setiap hari berbagai media massa selalu memberitakan perilaku menyimpang dari kepala daerah ataupun anggota DPRD, entah dalam kasus money politic pemilihan kepala daerah, pembahasan laporan pertanggungjawaban, korupsi dana $A P B D$, ataupun penjualan aset-aset pemerintah daerah dan lain-lain. Kasus-kasus yang mencuat tersebut secara langsung maupun tidak langsung telah menodai kepercayaan masyarakat, mereka berharap melalui otonomi daerah kehidupan demokrasi, kemasyarakatan, dan juga ekonomi akan lebih baik dari sebelumnya. Tetapi ternyata, otonomi baru berjalan \pm 4 tahun yang lebih banyak muncul kepermukaan justru penyimpanganpenyimpangan oleh para elit lokal yang kurang punya kepekaan terhadap penderitaan masyarakat dan kurang mampu menjalankan fungsi manajerial di daerah. Sehingga sisi positif dari otonomi daerah seolah menjadi terhalang oleh persoalan tersebut.Otonomi daerah bukannya mendatangkan berkah tetapi justru musibah bagi masyarakat di daerah.

Sudah bertahun-tahun kita menginginkan adanya penyelenggaraan pemerintahan daerah yang lebih desentralistik, karena selama pemerintahan Orde Baru warna sentralistik begitu kental melingkupi hubungan pusat dan daerah. Pemerintah daerah tidak pernah mendapat kesempatan untuk berkembang secara dinamis dan demokratis, semua serba ditentukan oleh pusat. Pemerintah Pusat seolah bertindak sebagai atasan bagi daerah, dan yang 'paling mengerti' apa kebutuhan daerah. Tidak heran apabila selama Orde Baru, daerah hanya menjadi 'sapi perah' dari berbagai kebutuhan dan kepentingan Pusat. "Restu" dari Pusat menjadi segala-galanya. Siapa yang memiliki akses ke Pusat itulah yang akan menjadi pemenang di daerah, baik untuk urusan politik, ekonomi, bahkan hukum sekalipun. 
Begitu pula dalam masalah hubungan antara kepala daerah dan DPRD. Cerita tentang ketidakharmonisan hubungan antara Kepala Daerah dan DPRD sudah sering terjadi sejak masa Orde Baru. Bedanya dengan saat sekarang (pasca Orde Baru), kalau di masa Orde Baru ketidakharmonisan itu akibat terlalu dominannya posisi Kepala Daerah dibanding posisi DPRD. DPRD sering merasd "dilecehkan" oleh Kepala Daerah. Sedangkan sekarang, DPRD posisinya lebih dominan (bahkan menentukan) dibanding posisi Kepala Daerahnya.

Adanya perubahan posisi antara Kepala Daerah dan DPRD tidak lepas dari perbedaan corak atau langgam peraturan perundang-undangan yang mengatur tentang pemerintahan daerah. Kalau UU No. 5 Tahun 1974 bercorak sentralistik, UU No. 22 Tahun 1999 lebih menampakkan semangat desentralistiknya, meskipun masih ada beberapa hal yang tidak bisa dihilangkan begitu saja corak sentralistiknya. Misalnya, pengaturan tentang perlunya pengesahan Presiden dalam pengangkatan dan pemberhentian Kepala Daerah.

Dalam pemilihan kepala daerah, melalui UU No. 22. Tahun 1999 telah dialihkan wewenang tersebut dari Presiden kepada DPRD. Presiden tidak lagi berwenang memilih kepala daerah sebagaimana dulu diatur dalam UU No. 5 Tahun 1974, tetapi wewenang itu sudah dilimpahkan kepada DPRD untuk memilih kepala daerahnya. Itulah wujud dari pemberdayaan politik daerah. Perubahan tersebut membawa implikasi yang sangat luas, kalau sebelumnya seorang calon untuk dapat menjadi kepala daerah harus 'minta restu' ke pusat dengan 'segala konsekuensinya', sekarang jalur itu seolah sudah terputus. Di era otonomi luas, seorang calon harus berjuang mati-matian di daerah untuk 'memenangkan' dukungan dari DPRD, tentu juga dengan 'segala konsekuensinya'. Dalam praktek, tidak sedikit calon kepala daerah yang -selain harus berjuang matimatian di daerah- juga masih harus minta restu "Pusat" (Pimpinan partainya), sehingga menjadi mahal biaya politiknya. Calon yang hanya "bermodal pas-pasan" tentu-akan berpikir berlipat-lipat untuk merealisasikan ambisinya. Masih 'beruntung' kalau bisa menang, tetapi kalau kalah dalam pemilihan padahal sudah terlanjur menghamburkan (menyuap) uang ratusan juta bahkan ada yang sampai miliaran rupiah, tentu akan menjadi cerita yang tragis dan menyedihkan.

Beranjak dari persoalan yang banyak muncul di daerah khususnya dalam pemilihan kepala daerah oleh DPRD, muncullah berbagai gagasan untuk mengkoreksi ulang sistem tersebut. Usulan yang nampaknya sudah mulai mengkristal adalah pemilihan kepala daerah secara langsung oleh rakyat. Hal ini dimaksudkan untuk mengurangi peluang terjadinya money politic dalam pemilihan kepala daerah, supaya lebih demokratis dan mencegah kemungkinan munculnya bakal calon yang tidak memiliki kemampuan dan kecakapan . baik manajerial, leadership, moralitas yang 'rendah' maupun akuntabilitas publik.

\section{Paradigma Baru dalam UU No. 22 Tahun 1999}

Dari sudut demokrasi, dalam arti formal, otonomi daerah diperlukan dalam rangka memperluas partisipasi masyarakat dalam pemerintahan. Dari segi materiil otonomi daerah mengandung makna sebagai usaha mewujudkan kesejahteraan yang bersandingan dengan prinsip negara kesejahteraan dan sistem pemencaran kekuasaan menurut dasar negara berdasarkan atas hukum. Oleh karena 
otonomi daerah bertalian dengan demokrasi, maka harus ada lembaga dan tata cara penyelenggaraan pemerintahan demokrasi di daerah.

Sejalan dengan sistem demokrasi perwakilan, maka secara kelembagaan pertu ada badan perwakilan rakyat daerah yang dibentuk secara demokratik. Demikian pula penyelenggaraan pemerintahannya harus dijalankan secara demokratik yang meliputi tata cara penunjukan pejabat, penentuan kebijakan, pertanggungjawaban, pengawasan, dan lain-lain. Mekanisme pemerintahan harus dilakukan dengan tata cara yang demokratik pula. ${ }^{1}$

Berdasarkan hal-hal tersebut lahirlah berbagai mekanisme demokratik, seperti sistem pemilihan anggota perwakilan, sistem pemilihan penyelenggara pemerintahan (bupati, walikota, gubernur), sistem hubungan tanggungjawab antara badan perwakilan dengan penyelenggara pemerintahan, dan lain sebagainya.

Sebelum otonomi daerah yang dikonstruksikan dalam UU No. 22 Tahun 1999 diterapkian di Indonesia, penyelenggaraan pemerintahan daerah diatur. menurut UU No. 5 Tahun 1974 yang dicirikan berwatak konservatif. ${ }^{2}$ Otonomi daerah yang diharapkan akan muncul sebagai amanat dari Pasal 11 - yang bertitik berat di Daerah Tingkat Il (Kabupaten dan Kota) - sampai berakhirnya keberlakuan UU tersebut tidak kunjung hadir. Otonomi hanya menjadi obsesi masyarakat di daerah. Sehingga wajar kalau masyarakat di daerah menuntut perubahan yang mendasar dalam pengelolaan negeri tercinta ini, khususnya dalam hubungan kelembagaan antara Pemerintah Pusat dan Daerah.

Beriringan dengan jatuhnya pemerintahan Soeharto, tuntutan otonomi semakin kencang datang dari daerah, bahkan ada daerah yang menuntut untuk memisahkan diri dari Negara Kesatuan Republik Indonesia. Mereka beranggapan bahwa selama ini hanya dijadikan "sapi perahan" Pemerintah Pusat, sementara kepentingan daerahnya terabaikan. Untuk itu, mereka menuntut adanya demokratisasi di daerah serta pembagian keuangan yang adil dan transparan antara Pemerintah Pusat dan Daerah.

Selama ini, dari sudut ekonomi, ketidakadilan Pemerintah Pusat terhadap Daerah tampak dari pengelolaan sumbersumber potensi daerah, dimana daerahdaerah yang kaya akan hasil tambang, hasil bumi, maupun hasil hutan, kurang mendapatkan perhatian yang seimbang dengan sumbangan yang mereka kirim ke Pusat. Semua pendapatan dari Daerah ditarik ke Pusat dan didistribusikan ulang dengan formula tertentu yang sangat tertutup. Kesenjangan inilah yang memicu ketegangan antara Pusat dan Daerah dari segi ekonomi.

Tekad Orde Baru menjamin stabilitas politik dalam rangka pembangunan ekonomi mempunyai implikasi tersendiri pada kehidupan partai-partai dan peranan lembaga perwakilan rakyat.

Dari sudut politik, UU No. 5 Tahun 1974 telah menciptakan pemerintahan yang

1. Bagir Manan, Menyongsong Fajar Otonomi Daerah, Yogyakarta: Pusat Studi Hukum Fakultas Hukum UII,2001, 'HIm. 59-60.

2. Produk hukum yang berwatak konservatif adalah produk hukum yang isinya lebih mencerminkan visi sosial elit politik, lebih mencerminkan keinginan pemerintah, bersifat positivis-instrumentalis, yakni menjadi alat pelaksanaan ideologi dan program negara. Lihat Moh. Mahfud MD., Politik Hukum di Indonesia, U!I Press kerjasama dengan LP3ES, Jakarta, 1998, HIm. 25. 
terpusat dan memberikan otonomi yang harus dipagari oleh kepentingan untuk mewujudkan keutuhan Negara Kesatuan. Tegasnya, UU No. 5 Tahun 1974 itu lahir dari semangat politik yang tidak demokratis karena program pembangunan berorientasi pada paradigma pertumbuhan sehingga UU tersebut tidak dapat menyembunyikan watak sentralistiknya. ${ }^{3}$

Bagi pemerintah Orde Baru, dikeluarkannya UU No. 5 Tahun 1974 merupakan salah satu perwujudan penataan birokrasi, yang arah tujuan penataan birokrasi tersebut y $a k n i$ : pertama, mengalihkan wewenang pemerintah ke tingkat birokrasi yang lebih tinggi yaitu proses pembuatan kebijakan pemerintah. Kedua, membuat birokrasi agar efektif dan tanggap pada perintah para pemimpin Pusat. Ketiga, memperluas wewenang pemerintah Orde Baru dan mengakomodasikan pengendalian atas daerah-daerah. ${ }^{4}$

Dewan Perwakilan Rakyat Daerah tidak diberikan wewenang politik yang memadai, karena semua putusan yang akan diambil harus dikonsultasikan lebih dahulu ke Pusat atau setidaknya kepada Kepala Daerah (Kepala Wilayah). Terhadap persoalan di daerah DPRD tidak dapat berbuat banyak kecuali harus selalu mendukung semua keinginan Kepala Daerah (Kepala Wilayah). UU No. 5 Tahun 1974 telah memandulkan aspirasi masyarakat di daerah karena wakilwakil mereka di DPRD tidak diberi wewenang untuk memilih, mengangkat, meminta pertanggungjawaban dan memberhentikan Képala Daerahnya. ${ }^{5}$ DPRD tidak dikonstruksi sebagai lembaga legislatif daerah yang berfungsi mengawasi kepala daerah dan jalannya pemerintahan di daerah, tetapi menjadi bagian dari kelembagaan pemerintah daerah (Pasal 1). Kepala Daerah diberi kekuasaan yang sangat kuat di daerah, sementara itu DPRD dibuat tidak berdaya.

Meskipun UU No. 5 Tahun 1974 telah melengkapi anggota DPRD dengan berbagai macam hak untuk dapat melaksanakan fungsinya, ${ }^{6}$ tetapi semua hak-hak DPRD tidak dapat diimplementasikan secara optimal, bahkan mungkin di beberapa daerah hak-riak itu "mandul". Sistem yang diciptakan tidak memungkinkan hak-hak itu dapat dilaksanakan oleh DPRD, karena caracara penggunaan hak-hak tersebut diatur didalam Peraturan Tata Tertib DPRD yang disusun sesuai pedoman yang telah ditetapkan oleh Menteri Dalam Negeri, dan untuk bisa melaksanakan hak tersebut mekanismenya sangat rumit (kalau tidak dapat dikatakan "dipersulit").

Kepala Daerah dalam konstruksi UU No. 5 Tahun 1974 justru dijadikan "mata-mata dan perpanjangan tangan" Pemerintah Pusat di Daerah dengan sebutan penguasa tunggal di daerah. Dalam diriKepala Daerah melekat dua jabatan sekaligus, sebagai kepala daerah dan kepala wilayah. Penempatan posisi kepala daerah yang demikian itu

3. Moh. Mahfud MD, "Pergeseran Politik Hukum Otonomi Daerah", Makalah Seminar Nasional Pergeseran Otonomi Daerah dan Demokratisasi di Indonesia, Kerjasama FH UII Yogyakarta dengan PERSAHI Jakarta, Yogyakarta, 5 Pebruari 1995, HIm. 1.

4. Mochtar Masoed, Ekonomi dan Struktur Politik Orde Baru, Jakarta:LP3ES,1989, HIm. 151.

5. Lihat Pasal 15 dan 16 beserta Penjelasan pasal tersebut.

6. Hak-hak DPRD sebagaimana diatur dalam Pasal 29 UU No. 5 Tahun 1974 meliputi: (a) anggaran; (b) mengajukan pertanyaan bagi masing-masing Anggota; (c) meminta keterangan; (d) mengadakan perubahan; (e) mengajukan pernyataan pendapat; prakarsa; (g) penyelidikan. 
sangat efektif mendukung kepentingan pemerintah Pusat tanpa ada satu kekuatan bargaining position untuk melawan kepentingan Pusat. Kepala Daerah diakhir masa jabatan harus bertanggungjawab kepada pemerintah Pusat, ${ }^{7}$ kepada DPRD hanya memberikan keterangan pertanggungjawaban. Hal ini sebagai konsekuensi logis dari kewenangan yang dimiliki oleh Pusat dalam hal mengangkat dan memberhentikan kepala daerah, karena hal. ini merupakan hak prerogatif presiden (Penjelasan Pasal 15 dan 16).

Setelah UU No. 5 Tahun 1974 diganti dengan UU No. 22 Tahun 1999, semangat dan harapan baru mulai muncul di tengahtengah masyarakat (Daerah). Melalui UU tersebut dilakukan berbagai terobosan baru terhadap kedudukan dan peranan lembaga perwakilan rakyat di daerah. Pertama, tidak lagi menempatkan DPRD sebagai bagian dari pemerintah daerah. Menurut UU No. 22 Tahun 1999 Pasal 1 huruf b, Pemerintah Daerah adalah kepala daerah beserta perangkat daerah otonom yang lain sebagai Badan Eksekutif Daerah. Sedangkan DPRD adalah badan legislatif daerah (Pasal 1 huruf c). Kedua, pemilihan kepala daerah dan wakil kepala daerah tidak lagi menjadi wewenang pemerintah Pusat tetapi DPRD diberi kewenangan untuk memilih kepala daerah dan wakil kepala daerah yang sesuai dengan aspirasi masyarakat setempat, Pemerintah Pusat tinggal mengesahkannya (Pasal 40 ayat (3)). Ketiga, dalam menjalankan tugas dan kewajibannya kepala daerah bertanggungjawab kepada DPRD (Pasal 44 Ayat (2)) dan wajib menyampaikan pertanggungjawaban kepada DPRD pada setiap akhir tahun anggaran (Pasal 45 Ayat (1)). DPRD juga berwenang untuk meminta pertanggungjawaban kepala daerah (Pasal 45 Ayat (2)), sehingga apabila pertanggungjawabannya ditolak oleh DPRD kepala daerah tersebut tidak bisa dicalonkan kembali pada periode berikutnya (Pasal 54). Keempat, DPRD dapat mengusulkan pemberhentian kepala daerah kepada Presiden apabila pertanggungjawaban kepala daerah ditolak untuk kedua kalinya oleh DPRD (Pasal 46 Ayat (3)). DPRD juga dapat memutuskan memberhentikan kepala daerah karena a' Pasal 49 dan kemudian keputusan tersebut disahkan oleh Presiden (Pasal 50).

Untuk dapat menjalankan berbagai fungsi yang ada pada dirinya, DPRD dibekali dengan berbagai macam hak yang tentu saja kalau dijalankan dengan baik akan mengakibatkan lembaga tersebut akan mampu memainkan peranan yang sangat kuat dalam menciptakan checks and balances dengan pihak eksekutif. ${ }^{8}$ Hak-hak anggota DPRD meliputi:

(a) meminta pertanggungjawaban Gubernur, Bupati, dan Walikota;

(b) meminta keterangan kepada Pemerintah Daerah;

(c) mengadakan penyelidikan;

(d) mengadakan perubahan atas Rancangan Peraturan Daerah; :

(e) mengajukan pernyataan pendapat;

(i) mengajukan Rancangan Peraturan Daerah;

(g) menentukan Anggaran Belanja DPRD; dan menetapkan Peraturan Tata tertib DPRD.

7. Dalam hal ini Gubernur bertanggungjawab kepada Presiden melalui Menteri Dalam Negeri, dan BupatiWalikota bertanggungjawab kepada Menteri Dalam Negeri melalui Gubernur (Pasal 22 ayat (2)).

B. Syaukani, Afan Gaffar dan M. Ryaas Rasyid, Otonomi Daerah Dalam Negara Kesatuan, Yogyakarta: Pustaka Pelajar kerjasama dengan Pusat Pengkajian Etika Politik dan Pemerintahan, 2002, HIm.192. 
Hak untuk meminta pertanggungjawaban Gubernur, Bupati, dan Walikota, adalah hal baru yang diperkenalkan oleh Undang-undang ini. Undang-undang Nomor 5 Tahun 1974 tidak memberikan hak ini pada DPRD tetapi hak meminta pertanggungjawaban secara hierarki ada pada Presiden (Pasal 22 ayat (2)). Yang diberikan kepada DPRD oleh Gubernur, Bupati, dan Walikotamadya hanyalah keterangan pertanggungjawaban (Pasal 22 ayat (3)).

Undang-undang No. 22 Tahun 1999 menyatakan bahwa tugas dan wewenang DPRD adalah:

(a) Memilih Gubernur/Wakil gubernur, BupatiWakil Bupati, dan Walikota/ Wakil Walikota.

(b) Memilih anggota Majelis Permusyawaratan Rakyat dari Utusan Daerah. ${ }^{9}$

(c) Mengusulkan pengangkatan dan pemberhentian Gubernur/Wakil Gubernur, BupatiWakil Bupati, atau Walikota/Wakil Walikota.

(d) Bersama dengan Gubernur, Bupati, atau Walikota membentuk Peraturan Daerah.

(e) Bersama dengan Gubernur, Bupati, atau Walikota menetapkan Anggaran Pendapatan dan Belanja Daerah.

(f) Melaksanakan pengawasan terhadap:

- Pelaksanaan Peraturan Daerah dan Peraturan Perundang-undangan lain.

- Pelaksanaan Keputusan Gubemur, Bupai' .'an Walikota.

- Pelaksanaan Anggaran, Pendapatan dan Belanja Daerah.

- Kebijaksanaan Pemerintah Daerahdan

- Pelaksanaan kerja sama internasional di Daerah.

(g) Memberikan pendapat dan pertimbangan kepada pemerintah terhadap rencana perjanjian internasional yang menyangkut kepentingan Daerah. (h) Menampung dan menindaklanjuti aspirasi daerah dan masyarakat.

Dalam hal tugas dan wewenang yang diberikan kepada DPRD juga mengalami penambahan atau perluasan yang sangat besar. Undang-undang No. 5 Tahun 1974 tidak pernah memberikan wewenang yang besar seperti ini, bahkan tugas dan wewenang DPRD dinyatakan secara tegas sebagai kewa;iban DPRD (Pasal 30).

Di samping itu, Undang-undang No. 22 Tahun 1999 juga melakukan pembaharuan, antara lain: Pertama, Fraksi bukan lagi merupakan alat kelengkapan DPRD (Pasal 17 ayat (3)). Yang hanya menjadi alat kelengkapan DPRD adalah Pimpinan, Komisi-Komisi, dan Panitia-Panitia. Kedua, Contempt of Parliament. Untuk pertama kalinya DPRD dapat memaksa seorang pejabat negara, atau pejabat pemerintah, atau bahkan warga negara kebanyakan untuk memberikan keterangan di hadapan DPRD, kalau memang lembaga tersebut merasa memerlukan keterangan atau informasi dari pejabat ataupun warga masyarakat. Dan apabila mereka menolak untuk memberikan keterangan di hadapan DPRD yang bersangkutan akan dapat dikenakan sanksi hokum berupa pidana kurungan paling lama satu tahun karena hal itu dianggap merendahkan martabat dan kehormatan DPRD (Pasal 20 ayat (1) dan (2)). ${ }^{.0}$

Demikian pula dalam pola hubungan kelembagaan antara Pemerintah Pusat dan Daerah terjadi perubahan yang signifikan. Kalau UU No. 5 Tahun 1974 dicirikan

9. Wewenang tersebut sudah dihilangkan karena adanya perubahan susunan keanggotaan MPR hasil sidang tahunan MPR 2001, Utusan Daerah sudah dihapuskan. Susunan MPR terdiri dari DPR dan DPD yang anggotanya dipilih langsung oleh rakyat.

10. Ibid., Hilm. 194-195. 
berwatak sentralistik maka UU No. 22 Tahun 1999 berwatak desentralistik. Melalui UU tersebut berbagai urusan yang selama ini diurus oleh Pemerintah Pusat sekarang dilimpahkan ke daerah. Kewenangan yang diurus oleh Daerah adalah semua bidang pemerintahan kecuali politik luar negeri, pertahanan keamanan, moneter dan fiscal, peradilan, agama, dan kewenangan lainnya antara lain perencanaan nasional dan pengendalian pembangunan nasional secara makro, dana perimbangan keuangan, system administrasi negara dan lembaga perekonomian negara, pembinaan dan pemberdayaan sumber daya manusia, pendayagunaan sumber daya alam serta teknologi tinggi yang strategis, konservasi, dan standarisasi nasional (Pasal 7).

Kewenangan Pemerintah yang diserahkan kepada Daerah dalam rangka desentralisasi itu akan disertai dengan penyerahan dan pengalihan pembiayaan, sarana dan prasarana, serta sumber daya manusia sesuai dengan kewenangan yang diserahkan tersebut (Pasal 8). Hal ini sangat berbeda pada masa sebelumnya, dimana penyerahan urusan ke daerah tidak disertai dengan pembiayaan, peralatan dan personil (3 P). Hal inilah yang selama ini menjadi keluhan Daerah dalam melaksanakan pembangunan di daerah.

Dengan kewenangan yang besar pada lembaga DPRD diharapkan proses demokrasi di daerah akan berjalan lebih baik dari sebelumnya. Anggota DPRD dituntut untuk memiliki kepekaan yang tinggi dan aspiratif terhadap tuntutan masyarakat di daerahnya. Dan yang harus dijaga adalah kepercayaan masyarakat terhadap lembaga (DPRD) tersebut, jangan sampai masyarakat menyangsikan atau kehilangan kepercayaan terhadap wakil-wakilnya di DPRD.

\section{Praktek Otonomi Daerah}

Belakangan ini memang banyak keluhan masyarakat terhadap wakilwakilnya di lembaga DPRD, baik dari segi perilaku, statement yang dilontarkan oleh anggota Dewan maupun tuntutan berbagai fasilitas bagi anggota Dewan dan terakhir disinyalir wakil-wakil rakyat "sulit menghin iar" dari jeratan politik uang dalam berbagai hal. Di samping itu, masyarakat juga melihat kinerja DPRD sangat mengecewakan. Hasil polling yang dilakukan oleh berbagai media massa menunjukkan, bahwa masyarakat di sebagian besar daerah di Indonesia belum merasakan hasil konkrit yang dilakukan oleh wakil-wakilnya di DPRD. Anggota DPRD masih banyak terjebak pada pemenuhan kepentingan pribadi dan kelompoknya, sementara kepentingan masyarakat belum teraktualisasi secara optimal. Otonomi yang diharapkan memberikan berkah bagi warga masyarakat ternyata baru dinikmati oleh elit politik lokal saja.

Begitu pun dalam kerangka hubungan antara Kepala Daerah dan DPRD juga masih banyak dijumpai masalah dalam implementasinya. Sinergitas kerja yang mutualisma antara Pemerintah Daerah dan DPRD juga belum sepenuhnya terwujud. Tidak jarang antara Kepala Daerah dan DPRD terjadi ketegangan dan rivalitas yang tinggi di berbagai daerah. Sebagai contoh, misalnya antara DPRD dengan Walikota Payakumbuh; DPRD dengan Walikota Surabaya, dan lain sebagainya).

Masyarakat juga seringkali dikecewakan oleh wakil-wakilnya, khususnya dalam pemilihan kepala daerah (Bupati/ Walikota). Di beberapa daerah di Jawa Timur, misalnya pilihan Bupati Sampang, Mojokerto, dan Walikota Surabaya, hasil pilihan DPRD ditolak oleh masyarakat. 
Selama ini kesan yang muncul, anggota DPRD cenderung arogan, kurang dewasa dalam bersikap, sumber daya manusianya kurang berkualitas, kurang pengalaman di bidang politik dan sebagian tidak membangun kariernya dari bawah, sehingga apa yang dihasilkan kurang memuaskan rakyat yang diwakilinya. Apakah itu berujud peraturan daerah, pengawasan terhadap kepala daerah, pemilihan kepala daєrah maupun dalam menjalin kemitraan dengan eksekutif daerah."

Kalau selama Orde Baru penyimpangan selalu dilakukan oleh oknum Pemerintah melalui UU No. 5 Tahun 1974, sekarang penyimpangan itu justru banyak dilakukan oleh oknum wakil-wakil rakyat di DPRD. Hal ini terjadi karena UU No. 22 Tahun 1999 tidak memberikan aturan secara tegas siapa yang akan mengawasi aktivitas kelembagaan DPRD, sehingga kalau terjadi penyimpangan yang dilakukan oleh anggota DPRD baik sendiri-sendiri atau secara kolektif (kelembagaan) UU No. 22 Tahun 1999 tidak memberikan solusi yang baik.

Kaiau pada masa sebelumnya (Orde Lama dan Orde Baru) ruang gerak DPRD diperketat, sekarang ketika ruang gerak DPRD diperluas kekuasaannya ternyata belum mampu memanfaatkan kekuasaan itu secara wajar, antara lain karena masih kurang pengetahuan dan minimnya pengalaman mengenai hakekat fungsi DPRD dan seluk beluk pengaturan dan caracara pengelolaan pemerintahan yang baik (good governance). Dalam berbagai peristiwa telah terjadi spanning hubungan antara DPRD dan Pemerintah Daerah. Keadaan makin "kelabu", karena dalam suasana kebebasan baru, berbagai kekuatan masyarakat memberikan bermacam-macam tekanan yang acapkali tidak proporsional lagi dalam suatu tatanan berdemokrasi yang menuntut rules of the game yang menjunjung tinggi hukum, yang damai, tertib, teratur, dan tenteram. Sebaliknya perlu pola kesadaran baru dari kepala daerah beserta jajarannya. Demokrasi memang menuntut agar DPRD dapat berperan secara wajar, dan menuntut keterbukaan. Kepala daerah dan jajarannya bukan alat kekuasaan sentralisme yang lebih menampakkan diri sebagai pangreh dengan simbol-simbol dan tingkah laku otoritarian, melainkan sebagai penyelenggara pemerintahan yang bertanggungjawab dan harus tunduk pada pengawasan publik untuk mewujudkan kesejahteraan umum di daerahnya. ${ }^{2}$

\section{Posisi Pemerintah Pusat di Era Otonomi Luas}

Berbeda dengan masa sebelumnya, ketika berlakunya UU No. 5 Tahun 1974, peran Pemerintah Pusat sangat dominan dalam menentukan garis kebijaksanaan Pemerintahan di Daerah. Hampir dapat dipastikan kecil kemungkinan Daerah dapat bergerak secara leluasa mengatur dirinya sendiri, baik dalam proses pemilihan Kepala Daerah, Pembuatan Peraturan Daerah, Penyusunan dan Pengelolaan Anggaran Pendapatan Belanja Daerah, Kebijakan Pembangunan Daerah, dan seterusnya.

Meskipun gagasan awal penataan pemerintahan di daerah yang kemudian dituangkan di dalam UU No. 5 Tahun 1974 dimaksudkan untuk mewadahi gagasan otonomi daerah sebagai implementasi prinsip demokrasi, namun dalam kenyataannya sistem hubungan antara

11. Ni'matul Huda, "Otonomi Luas (Perspektif Yuridis dan Politis)", Jumal Studi Agama Millah Vol. 1, No. 1, Agustus 2001, Hlm. 92.

12. Bagir Manan, Menyongsong ...op.cit., HIm. xi-xii. 
Pusat dan Daerah adalah sistem hubungan yang sentralistik. Hal ini dapat terlihat dari proses pemilihan dan penentuan kepala daerah. Pasal 15 menegașkan:

(1) Kepala Daerah Tingkat I dicalonkan dari dipilih oleh DPRD dari sedikitdikitnya 3 (tiga) orang dan sebanyakbanyaknya 5 (lima) orang calon yang telah dimusyawarahkan dan disepakati bersama antara Pimpinan DF:RD/ Pimpinan Fraksi-Fraksi dengan Gubernur

(2) Hasil pemilihan yang dimaksud dalam ayat (1) pasal ini diajukan oleh DPRD yang bersangkutan kepada Presiden melalui Menteri Dalam Negeri sedikitdikitnya 2 (dua) orang untuk diangkat salah séorang diantaranya.

Kemudian di dalam Penjelasan Pasa! 16 disebutkan, Presiden dalam mengangkat Kepala Daerah dari antara calon-calon yang diajukan oleh DPRD, tidak terikat pada jumlah suara yang diperoleh masing-masing calon, karena hal ini adalah merupakan hak prerogatif Presiden. Hal yang sama juga terjadi dalam pemilihan Kepala Daerah Tingkat II, Menteri Dalam Negeri yang dalam hal ini bertindak atas namia Presiden dalam mengangkat Kepala Daerah Tingkat II tidak terikat pada jumlah suara yang diperoleh masing-masing calon (Penjelasan Pasal 16). Ketentuan tersebut secara jelas sangat tidak demokratis dan melecehkan aspirasi masyaräkat di daerah, sehingga berapapun jumlah suara yang diperoleh seorang calon menjadi tidak penting lagi, karena kuncinya bukan pada jumlah dukungan suara tetapi pada kehendak Presiden yang dibungkus dengan kata hak prerogatif. ${ }^{13}$

Intervensi Pusat dalam perundangundangan di daerah juga nampak pada kewenangan dalam pengawasan terhadap Daerah yang berupa: pengawasan umum, pengawasan preventif dan pengawasan represif. ${ }^{14}$ Melalui ketiga macam pengawasan tersebut Pemerintah Pusat dapat secara efektif mengontrol kebijakan Daerah. Peraturan Daerah atau Keputusan Kepala Daerah yang menguntungkán kepentingan Pemerintah Pusat akan segera disahkan, tetapi sebaliknya, jika ada Peraturan Daerah dan Keputusan Kepala Daerah yang justru 'mengancam' dominasi Pusat atau mengurangi keleluasaan Pusat di Daerah pasti akan ditolak pengesahannya. Disamping itu, Pemerintah Pusat juga berwenang menangguhkan atau memba-

13. Lihat kasus-kasus yang pernah mencuat di masa Orde Baru, misalnya: Ismail Suko, Sri Roso Sudarmo, Warsito Rasman dan seterusnya, menunjukkan betapa dominasi Pusat sangat kental.

14. Pengawasan umum adalah suatu jenis pengawasan yang dilakukan oleh pemerintah terhadap segala kegiatan Pemerintah Daerah untuk menjamin penyelenggaraản pemerintahan Daeráh dengan baik. Pengawasan Umum terhadap pemerintah Daerah dilakukan oleh menteri Dalam negeri dan Gubernur/Bupati/Walikotamadya Kepala Daerah sebagai Wakil pemerintah di daerah yang bersangkutan. Pengawasan Preventif mengandung prinsip bahwa Peraturan daerah dan Keputusan Kepala daerah mengenai pokok tertentu baru berlaku sesudah ada pengesahan pejabat yang berwenang, yaitu: (a) Menteri Dalam Negeri bagi Peraturan Daerah dan Keputusan Kepala Daerah Tingkat I; (b) Gubernur Kepala Daerah bagi Peraturan Daerah dan Keputusan Kepala Daerah Tingkat II. Pengawasan Represif dilakukan terhadap semua Peraturan Dearah dan Keputusan Kepala Daerah; Pengawasan Represif berwujud penangguhan atau pembatalan Peraturan Daerah atau keputusan Kepala daerah yang bertentangan dengan kepentingan umum dan peraturan perundang-undangan yang lebih tinggi tingkatannya. Penangguhan atau pembatalan itu dilakukan oleh pejabat yang berwenang. 
talkan suatu Peraturan Daerah atau Keputusan Kepala Daerah yang menurutnya bertentangan dengan kepentingan umum dan peraturan perundang-undangan yang lebih tinggi, dengan tolok ukur yang ditentukan sendiri oleh Pusat.

Sekarang, di era otonomi luas (UU No. 22 Tahun 1999) bentuk pengawasan yang dilakukan oleh Pemerintah Pusat lebih ditekankan pada pengawasan represif, hal ini dimaksudkan untuk lebih memberikan kebebasan kepada daerah otonom dalam mengambil keputusan serta memberikan Feran kepada DPRD dalam mewujudkan fungsinya sebagai badan pengawas terhadap pelaksanaan otonomi daerah. Karena itu, Peraturan Daerah yang ditetapkan Daerah Otonom tidak memerlukan pengesahan terlebih dahulu oleh pejabat yang berwenang.

Meskipun demikian, Pemerintah dapat membatalkan Peraturan Daerah dan Keputusan Kepala Daerah yang bertentangan dengan kepentingan umum atau peraturan perundang-undangan yang lebih tinggi dan/atau peraturan perundangundangan lainnya. Daerah yang tidak dapat menerima keputusan pembatalan Peraturan Daerah dan Keputusan Kepala Daerah dapat mengajukan keberatan kepada Mahkamah Agung setelah mengajukannya kepada Pemerintah (Pasal 114). ${ }^{15}$

Berkaitan dengan masalah pemilihan kepala daerah, nuansa yang dibangun UU No. 22 Tahun 1999 sangat berbeda dengan UU No. 5 Tahun 1974. Di dalam Pasal 40 ayat (3) UU No. 22 Tahun 1999 ditegaskan, "Pasangan calon Kepala Daerah dan calon Wakil Kepala Daerah yang memperoleh suara terbanyak pada pemilihan, sebagaimana dimaksud pada ayat (2), ditetapkan sebagai Kepala Daerah dan Wakil Kepala Daerah oleh DPRD dan disahkan oleh Presiden." Begitu pula dalam hal pemberhentian Kepala Daerah. Pemberhentian Kepala Daerah ditetapkan dengan Keputusan DPRD dan disahkan oleh Presiden (Pasal 50 ayat (1)). Adanya pengesahan dari Presiden tentu dimaksudkan antara lain untuk memberi penegasan bahwa mekanisme yang dilalui dalam proses pemilihan kepala daerah sudah sesuai dengan peraturan perundang-undangan yang berlaku. Akan tetapi, jika adanya pengesahan Presiden dalam masalah ini dimaksudkan untuk "klep pengaman" kepentingan tertentu Pemerintah Pusat di Daerah, sebagaimana yang pernah dipraktekkan di masa Orde Baru, tentu pengaturan yang seperti itu akan kontra produktif terhadap demokrasi yang ingin dibangun dan diujudkan di Daerah. ${ }^{16}$

Demikian halnya, syarat adanya pengesahan dari Presiden atas keputusan DPRD dalam pemberhentian Kepala Daerah sebagaimana yang diatur didalam Pasal 50

15. Untuk masalah ini MPR melalui Sidang Tahunan 2001 telah memberikan rekomendasi kepada Mahkamah Agung untuk melakukan judicial review terhadap Peraturan Daerah (Perda) "bermasalah" yang bertentangan dengan peraturan perundangundangan yang lebih tinggi, tanpa melalui proses peradilan kasasi sesuai Pasal 5 TAP MPR No. III/MPR/2000. Lihat dalam Ketetapan MPR No. X/MPR/2001 tentang Laporan Pelaksanaan Putusan MPR RI Oleh Lembaga Tinggi Negara Pada Sidang Tahunan MPR RI Tahun 2001. Selama berlakunya UU No. 22 Tahun 1999 Pemerintah telah membatalkan 68 Peraturan Daerah yang bertentangan dengan peraturan yang lebih tinggi, di tahun 2001.

16. Sebagai contoh dalam persoalan ini bisa kita lihat, misalnya kasus Calon terpilih Gubernur Lampung. Gubernur Sumatera Selatan, Gubernur Maluku, Bupati Karanganyar dan lain-lainnya. 
ayat (2) UU No. 22 Tahun 1999, tentu juga dimaksudkan sebagai "klep pengaman" terakhir, jangan sampai ada kepala daerah yang diperlakukan secara tidak adil oleh DPRD dan kemudian dijatuhkan secara sewenang-wenang. Akan tetapi, jika pengesahan tersebut justru dipakai sebagai "klep pengaman" atas kepentingankepentingan politik tertentu atau sebagai bentuk intervensi dari Perr.srintah Pusat, maka ketentuan dalam Pasal 50 ayat (2) tersebut akan menjadi batu sandungan bagi proses demokrasi di daerah. Bukan tidak mungkin akan muncul konflik-konflik baru di masyarakat.

Keharusan adanya pengesahan dari Presiden secara umum dipahami sebagai campur tangan Pusat terhadap Daerah. Hal ini menunjukkan bahwa UU No. 22 Tahun 1999 masih juga menyisakan unsur sentralistiknya. Suatu hal yang bertolak belakang dengan kehendak memberikan otonomi luas kepada daerah.

Ketakutan masyarakat akan terjadi sentralisasi kekuasaan dan sikap tidak demokratis dari Pemerintah Pusat tentu akan menjadi penghalang atas keinginan Pemerintah merevisi UU No. 22 Tahun 1999. Dengan kata lain, apabila Presiden menolak mengesahkan hasil pemilihan atau pemberhentian kepala daerah yang sudah diputuskan oleh DPRD yang merupakan representasi kehendak rakyat, maka otonomi yang berisi kebebasan dan kemandirian daerah menjadi kehilangan makna. Presiden harus sungguh-sungguh menghormati kehendak DPRD sebagai penjelmaan kedaulatan rakyat dari daerah tersebut. Penolakan pengesahan Presiden akan mempersulit hubungan kepala daerah dengan DPRD. Pemerintahan di daerah tidak akan dapat berjalan sebagaimana mestinya.

\section{Wacana Pemilihan Kepala Daerah Secara Langsung}

Disadari:bahwa pembentukan UU No. 22 Tahun 1999 diselimuti oleh semangat reformasi di segala aspek kehidupan bernegara, berlangsung secara cepat sehingga pada akhirnya dirasakan ada substansi atau praktek penyelenggaraannya yang kurang sesuai dengan jiwa dan semangat berdemokrasi dalam Negara Kesatuan RI.

Adanya kekurangan dalam UU No. 22 Tahun 1999 telah disadari oleh para wakil rakyat yang duduk di MPR RI yang melahirkan ketetapan MPR No. IVIMPR/ 2000 tentang Rekomendasi Kebijakan dalam Penyelenggaraan Otonomi Daerah. Bersamaan dengan itu dalam Sidang Tahunan MPR RI tahun 2000 telah dilakukan Perubahan Kedua UUD 1945 yang antara lain telah merubah Bab VI tentang Pemerintahan Daerah dengan Pasal 18, Pasal 18A, dan Pasal 18B sehingga dikeluarkannya Ketetapan MPR No. IV/MPR/2000 tersebut sejalan dengan perubahan UUD 1945. Salah satu butir rekomendasi menyebutkan: "Sejalan dengan semangat desentralisasi, demokrasi, dan kesetaraan hubungan pusat dan daerah diperlukan upaya perintisan awal untuk melakukan revisi yang bersifat mendasar terhadap UU No. 22 Tahun 1999 tentang Pemerintahan Daerah. Revisi dimaksud dilakukan sebagai upaya penyesuaian terhadap Pasal 18 UUD 1945..." Atas dasar amanat TAP MPR di atas, kebutuhan untuk melakukan revisi terhadap UU No. 22 Tahun 1999 tidak terelakkan, apalagi Pasal 18 UUD 1945 yang menjadi dasarnya, pada perubahan kedua UUD 1945 telah disempurnakan dan 
ditambah menjadi semakin jelas dan rinci. ${ }^{17}$

Peninjauan dan penyesuaian dalam UU No. 22 Tahun 1999 yang perlu dilakukan adalah mengenai pemilihan kepala daerah dan wakil kepala daerah dengan segala aspek yang terkait dengan perubahan tersebut. Hal ini sudah dimulai dengan perubahan dari UU No. 4 Tahun 1999 tentang Susunan dan Kedudukan MPR, DPR, dan DPRD menjadi UU No. 22 Tahun 2003 tentang Susunan dan Kedudukan MPR, DPR, DPD dan DPRD yang didalamnya tidak lagi tercantum kewenangan DPRD untuk memilih kepala daerah.

Perubahan kedua UUD 1945 Pasal 18 ayat (4) menyatakan bahwa Gubernur, Bupati, dan Walikota masing-masing sebagai kepala pemerintahan provinsi, kabupaten, dan kota dipilih secara demokratis. Pemakaian kata demokratis tersebut memiliki dua makna, yaitu baik pemilihan langsung maupun tidak langsung melalui DPRD kedua-duanya demokratis. Setelah UUD 1945 diamandemen (2001), terjadi perubahan dalam system pemilihan Presiden dan Wakil Presiden, yakni secara langsung oleh rakyat. Sementara itu, model pemilihan kepala daerah menurut UU No. 22 Tahun 1999 dipilih tidak langsung oleh rakyat tetapi melalui lembaga perwakilan yaitu DPRD. ${ }^{19}$ Model lainnya yang diatur secara khusus, misalnya dalam UU No. 18 Tahun 2001 tentang Otonomi Khusus Bagi Provinsi Daerah Istimewa Aceh Sebagai Provinsi Nanggroe Aceh Darussalam (NAD). Di dalam UU tersebut ditegaskan, Gubernur dan Wakil Gubernur Provinsi NAD dipilih secara langsung setiap 5 (lima) tahun sekali melalui pemilihan yang demokratis, bebas, rahasia serta dilaksanakan secara jujur dan adil. Demikian pula untuk pemilihan Bupati/ Wakil Bupati dan Walikota/Wakil Walikota, juga dipilih langsung. ${ }^{19}$ Model yang lain lagi dan banyak disorot oleh masyarakat adalah yang berlaku di Daerah Istimewa Yogyakarta. Di daerah ini, gubernur dan wakil gubernur tidak dipilih oleh DPRD ataupun rakyat secara langsung tetapi melalui pengangkatan. Dengan kata lain, sampai saat ini UU No. 22 Tahun 1999 masih memberikan keistimewaan kepada DIY berupa pengangkatan Gubernur dengan mempertimbangkan calon dari is eturunan Sultan Yogyakarta dan Wakil Gubernur dengan mempertimbangkan calon dari keturunan Paku Alam yang memenuhi syarat. Untuk pemilihan kepala desa, justru sudah lama dipraktekkan dilakukan pilihan langsung oleh rakyat.

Dari uraian di atas terlihat bahwa model pemilihan kepala daerah yang dipraktekkan di daerah selama ini (pasca Orde Baru) bervariatif, untuk itu perlu ada penyempurnaan dalam sistem, bahwa tuntutan masyarakat menghendaki pemilihan langsung untuk kedudukan kepala pemerintahan dari tingkat pusat sampai ke desa.

Pemilihan langsung kepala daerah oleh rakyat akan membawa beberapa implikasi lainnya yang perlu diatur substansinya dalam undang-undang pemerintahan daerah seperti menyangkut tugas dan wewenang

17. Lihat dalam "Keterangan Pengusul atas RUU RI tentang Perubahan Atas Uu No. 22 Tahun 1999 tentang Pemerintahan Daerah, tanggal 10 September 2003 oleh Badan Legislatif DPR RI."

. 19. Didalam UU No. 21 Tahun 2001 tentang Otonomi Khusus Bagi Provinsi Papua, pemilihan kepala daerah dilakukan oleh Dewan Perwakilan Rakyat Papua (DPRD) dengan memperhatikan pertimbangan dan persetujuan terhadap bakal calon dari Majelis Rakyat Papua (MRP).

19. Lihat Pasal 12 dan Pasal 15 UU No. 18 Tahun 2001. 
DPRD, hubungan antara DPRD dan Kepala Daerah, serta penyelenggaraan pemilihan kepala daerah.

\section{Penutup}

Mekanisme pemilihan kepala daerah yang diatur baik oleh UU No. 22 Tahun 1999 maupun Peraturan Pemerintah No. 151 Tahun 2000 se .nngguhnya sudah sangat rinci memberikan rambu-rambu bagaimana pemilihan kepala daerah harus dilaksanakan. Yakni melalui beberapa tahapan yang berupa; pendaftaran, penyaringan, penetapan pasangan calon, rapat paripurna khusus, pengiriman berkas pemilihan, pengesahan, dan pelantikan. Semua tahapan tersebut dirancang agar Kepala Daerah terpilih adalah benar-benar seorang pemimpin yang memenuhi kualifikasi administratif yang disyaratkan, mengenal dan dikenal oleh masyarakat, memiliki kompetensi dan kapabilitas memimpin daerah, serta memiliki moralitas yang baik:

Di dalam prakteknya, tidak sedikit kita jumpai berbagai penyimpangan dari aturan main yang ada, sehingga hasil yang ingin dicapai pun tidak optimal atau masih jauh dari standar kelayakan untuk memimpin daerah.

Wacana pemilihan kepala daerah secara langsung oleh rakyat yang terus bergulir di masyarakat hendaknya dilakukan kajian secara mendalam, sejauhmana kesiapan masyarakat dan pemerintah untuk menyelenggarakannya. Berbagai instrumen yuridis yang akan dipakai untuk proses tersebut harus sudah benar-benar disiapkan secara matang. Jangan sampai hasilnya sama saja dengan sebelumnya, atau bahkan lebih parah.

\section{Daftar Pustaka}

Manan, Bagir, 2001, Menyongsong Fajar Otonomi Daerah, Yogyakarta: Pusat Studi Hukum Fakultas Hukum Uli.

Mas'oed,Mochtar, 1989, Ekonomi dan Struktur Politik Orde Baru, Jakarta: LP3ES).

Moh. Mahfud MD., "Pergeseran Politik Hukum Otonomi Daerah", Makalah Seminar Nasional Pergeseran Otonomi Daerah dan Demokratisasi. di Indonesia, Kerjasama Fakultas Hukum UII dengan PERSAHI Jakarta, Yogyakarta, 5 Februari 1995.

Moh. Mahfud MD.,1998, Politik Hukum di Indonesia, (Yogyakarta:Ull Press bekerjasama dengan Jakarta: LP3ES).

Syaukani HR, Afan Gaffar dan Ryaas Rasyid, 2002, Otonomi Daerah Dalam Negara Kesatuan, Yogyakarta: Pustaka Pelajar kerjasama dengan Pusat Pengkajian Etika Politik dan Pemerintahan.

Keterangan Pengusul atas RUU RI Tentang Perubahan Atas UU No. 22 Tahun 1999 tentang Pemerintahan Daerah oleh Anggota DPR RI, 10 September 2003.

Ketetapan MPR RI No. X/MPR/2001 tentang Laporan Pelaksanaan Putusan MPR Rl oleh Lembaga Tinggi Negara Pada Sidang Tahunan MPR RI Tahun 2001.

UU No. 5 Tahun 1974 tentang Pemerintahan di Daerah. 
Topik: Pemilu dan Pemilihan Presidén \& Wakil Presiden

UU No. 22 Tahun 1999 tentang Peme- Jurnal Studi Agama Millah, Vol. 1, No. 1, rintahan Daerah. Agustus 2001.

UU No. 18 Tahun 2001 tentang Otonomi Gatra, 2 Februari 2002.

Khusus Bagi Provinsi Daerah Istimewa Aceh Sebagai Provinsi Kompas, 16 Januari 2002. Nanggroe Aceh Darussalam (NAD).

UU No. 21 Tahun 2001 tentang Otonomi Khusus Bagi Provinsi Papua Kompas, 23 Januari 2002.

Kompas, 29 Januari 2002.

\section{वप}

